\title{
ANALISIS FAKTOR PENDUKUNG DAN FAKTOR PENGHAMBAT DALAM PELAKSANAAN PEMANFAATAN ASET TETAP BADAN LAYANAN UMUM (BLU): STUDI KASUS PADA POLITEKNIK KEUANGAN NEGARA STAN
}

\author{
Trisepti Wahyuningsih ${ }^{1)^{*}}$, Nanda Ayu Wijayanti ${ }^{2)}$ \\ ${ }^{1}$ Fakultas Ekonomi dan Bisnis, Universitas Indonesia \\ email: trisepti.w@gmail.com \\ ${ }^{2}$ Fakultas Ekonomi dan Bisnis, Universitas Indonesia \\ email: nandarahman@,gmail.com
}

\begin{abstract}
This study aims to analyze the factors that support and hinder the implementation of the utilization of fixed assets in BLU with a case study on PKN STAN. PKN STAN is one of the BLU of education in Indonesia. The factors used to refer to agency theory, rational choice theory, Edward III theory, and a review of previous research. This research uses an explorative qualitative analysis method. Data collection uses virtual semistructured in-depth interview techniques. The results showed that the supporting factors for the utilization of fixed assets in BLU are Human Resources, Regulation, Supervision and Control, the Role and Commitment of Leader, and Tariff. Whereas, the inhibiting factors are Activity Management, Human Resources, Regulation, the Role and Commitment of the Leader, and Governance. This research implies that BLU has a significant role in optimizing the utilization of its fixed assets through Human Resources management and activity management. Besides, regulators also play a role in strengthening the flexibility of BLU within the scope of the utilization of fixed assets through clear regulations.
\end{abstract}

Keywords: Fixed asset utilization; PKN STAN; public service agency (BLU)

\begin{abstract}
ABSTRAK
Penelitian ini bertujuan untuk menganalisis faktor-faktor yang mendukung dan menghambat pelaksanaan pemanfaatan aset tetap di BLU dengan studi kasus pada PKN STAN. PKN STAN merupakan salah satu BLU pendidikan di Indonesia. Faktor-faktor yang digunakan merujuk pada teori keagenan, teori pilihan rasional, teori Edward III, dan tinjauan penelitian terdahulu. Penelitian ini menggunakan metode analisis kualitatif eksploratif. Pengumpulan data menggunakan teknik semi-structured in-depth interview secara virtual. Hasil penelitian menunjukkan bahwa faktor pendukung pelaksanaan pemanfaatan aset tetap di BLU adalah SDM, Peraturan, Pengawasan dan Pengendalian, Peranan dan Komitmen Pimpinan, serta Tarif. Sedangkan, faktor yang menghambat adalah Manajemen Kegiatan, SDM, Peraturan, Peranan dan Komitmen Pimpinan, serta Tata Kelola. Implikasi penelitian ini adalah BLU berperan penting dalam optimalisasi pemanfaatan aset tetap melalui penataan SDM dan manajemen kegiatan. Selain itu, para regulator turut berperan untuk menguatkan fleksibililitas BLU dalam lingkup pemanfaatan aset tetap melalui peraturan yang jelas.
\end{abstract}

Kata Kunci: Badan Layanan Umum (BLU); pemanfaatan aset tetap; PKN STAN 


\section{PENDAHULUAN}

Seiring dengan reformasi birokrasi saat ini muncul paradigma baru, salah satunya dalam pengelolaan aset pemerintah. Aset yang dulu menjadi cost center, sekarang dituntut agar menjadi revenue center (Waloejo, 2015). Guna mendorong pencapaian tersebut, instansi pemerintah berbentuk BLU diberi fleksibilitas yang luas untuk memperoleh pendapatan, tetapi tujuannya tidak untuk mencari keuntungan. Akhirnya, untuk mendorong BLU men-generate income, salah satu kewenangan yang diberikan adalah dengan optimalisasi aset yang dimiliki melalui pemanfaatan aset tetap.

Secara umum, pengelolaan aset pada BLU diatur dalam Peraturan Menteri Keuangan Nomor 136/PMK.05/2016 tentang Pengelolaan Aset pada Badan Layanan Umum. Menurut PMK tersebut, proses pengelolaan aset pada BLU meliputi perencanaan dan penganggaran, penggunaan, pemanfaatan, pemindahtanganan, pemusnahan, serta penghapusan. Dari proses tersebut, pemanfaatan merupakan siklus pengelolaan aset yang sangat penting karena menjadi satu-satunya kegiatan yang dapat menghasilkan pendapatan. Pendapatan tersebut dapat digunakan langsung untuk membiayai belanja yang dikeluarkan (Putra, 2015).

Selain itu, sesuai dengan rencana strategis Kementerian Keuangan 20152019, optimalisasi pemanfaatan aset juga menjadi salah satu concern pemerintah dalam rangka meningkatkan pendapatan negara. Selaras dengan teori pilihan rasional yang dikemukakan oleh Coleman dan Fararo (1992) dalam Sulistiawati (2016) dan Sugiri (2016), hal tersebut bisa menjadi motivasi bagi pengelola BLU untuk meningkatkan pendapatan dari hasil pemanfaatan. Oleh karena itu, faktor Sumber Daya Manusia (SDM) selaku pengelola BLU menjadi sangat krusial. Mengacu pada teori Edward III dalam Simamora dan Halim (2015), SDM yang berperan dalam pengelolaan aset tidak hanya staf, tetapi juga pimpinan.

Di sisi lain, karena statusnya sebagai BLU, maka dalam pemanfaatan aset diharuskan tunduk pada peraturan dari beberapa pihak, antara lain Direktorat Pembinaan Pengelolaan Keuangan BLU (PPK BLU) selaku Pembina BLU dan Direktorat Jenderal Kekayaan Negara (DJKN) selaku Pengelola Barang. Dalam praktiknya, hal tersebut menjadi faktor yang menyebabkan keraguan dari pengelola BLU, terutama pimpinan dalam mengambil keputusan terkait pemanfaatan aset karena adanya dualisme peraturan antar regulator tersebut.

Selain itu, dari hasil tinjauan beberapa penelitian terdahulu mengungkapkan bahwa pelaksanaan pemanfaatan aset di instansi pemerintah belum berjalan efektif. Salah satunya adalah penelitian Purba (2019) yang menyebutkan bahwa faktor tata kelola dapat mengakibatkan pelaksanaan pemanfaatan aset berjalan tidak efektif. Masih banyak satuan kerja (satker) yang melakukan fraud, diantaranya tidak menyetorkan hasil pemanfaatan aset karena tata kelola yang masih belum bagus. Di sinilah faktor pengawasan dan pengendalian sangat diperlukan. Sesuai dengan yang diungkapkan Setyaningrum (2015) bahwa perlu adanya monitoring untuk mengatasi masalah keagenan yang salah satu jenisnya adalah antara pemerintah sebagai principal dengan birokrat dalam hal ini BLU sebagai agen.

PKN STAN menjadi satu-satunya BLU pendidikan yang menyelenggarakan pendidikan tanpa memungut biaya dari peserta didik, padahal BLU didorong untuk men-generate income. Sementara itu sebagai BLU, PKN STAN tidak boleh hanya bergantung pada anggaran yang diberikan kementerian induk. Sehingga, PKN STAN perlu menggali pendapatan dari layanan yang diberikan. Namun, kondisinya yang tidak dapat memperoleh pendapatan dari layanan utama, 
seharusnya para pengelola memerhatikan strategi yang dapat menghasilkan pendapatan dari layanan pendukung, yaitu melalui pemanfaatan aset.

Pemanfaatan aset di PKN STAN dirasa sangat potensial. PKN STAN memiliki aset tetap dalam jumlah banyak yang dapat dijadikan objek pemanfaatan. Aset tetap dalam hal ini adalah tanah dan bangunan yang tercatat dalam Sistem Informasi Manajemen Aset Negara (SIMAN) 2020 memiliki luas sebesar $282.858 \mathrm{~m}^{2}$, serta berada di lokasi strategis. Namun, praktiknya, pendapatan dari hasil pemanfaatan aset dirasa masih sangat rendah dibanding dengan nilai tanah dan bangunan. Berdasarkan laporan pengawasan dan pengendalian, serta laporan keuangan PKN STAN, persentase hasil pemanfaatan di PKN STAN dibanding nilai tanah dan bangunan sangat kecil, yaitu hanya sebesar $0,0098 \%$ pada tahun 2017.

Bahkan, di dua tahun berikutnya mengalami penurunan persentase menjadi sebesar $0,0077 \%$ di tahun 2018 dan $0,0074 \%$ di tahun 2019. Sehingga, penelitian ini dilakukan dengan tujuan untuk menggali faktor apa saja yang menghambat pelaksanaan pemanfaatan aset di PKN STAN, serta faktor apa saja yang dapat mendukung pelaksanaan pemanfaatan aset. Sebagai satu-satunya BLU pendidikan yang berada di bawah Kementerian Keuangan dimana instansi Pembina BLU dan Pengelola Barang berada, PKN STAN diharapkan dapat menjadi pilot project implementasi kebijakan terkait pemanfaatan aset di BLU.

\section{KAJIAN LITERATUR}

\section{Teori Keagenan}

Menurut teori keagenan yang diungkapkan Jensen dan Meckling (1976) dalam Setyaningrum (2015), masalah keagenan dapat dipicu oleh hubungan kontraktual antara principal dan agen. Masalah keagenan tersebut muncul karena adanya informasi asimetri antara principal dan agen yang salah satunya menyebabkan moral hazard. Salah satu kegiatan yang dapat mengatasi moral hazard adalah monitoring. Menurut Streim (1994) dalam Setyaningrum (2015), terdapat tiga jenis hubungan keagenan dalam konteks pemerintahan. Penelitian ini memfokuskan pada jenis hubungan keagenan antara pemerintah sebagai principal dengan birokrat dalam hal ini adalah BLU sebagai agen.

\section{Teori Pilihan Rasional}

Konsep dari teori pilihan rasional yang dikemukakan oleh Coleman dan Fararo (1992) dalam Sulistiawati (2016) adalah bagaimana aktor berusaha memaksimalkan manfaat dari sumber daya yang ada untuk memenuhi kebutuhan mereka. Teori tersebut banyak digunakan saat proses pengambilan keputusan dengan pendekatan analisis. Lee, Johnson, dan Joyce (2013) dalam Sugiri (2016) menyebutkan beberapa langkah logis dalam pendekatan tersebut, yaitu pertama, organisasi memeringkat kebutuhan berdasarkan skala prioritas. Kedua, organisasi mengidentifikasi semua alternatif yang dapat diambil untuk memenuhi kebutuhan. Ketiga, organisasi menentukan alternatif yang paling dapat memenuhi kebutuhan. Alternatif dengan biaya paling rendah dan/atau yang memberikan hasil paling tinggilah yang dipilih.

\section{Teori Edward III}

Pelaksanaan pemanfaatan aset di BLU merupakan salah satu implementasi kebijakan publik. Menurut teori Edward III dalam Simamora dan Halim (2015), terdapat empat faktor yang memengaruhi implementasi kebijakan publik, yaitu komunikasi, sumber daya, sikap, dan struktur birokrasi. Hasil penelitian Inayah (2010) dalam Simamora dan Halim (2015) menunjukkan bahwa sumber daya menjadi faktor yang dominan memengaruhi implementasi kebijakan pengelolaan aset. Kemudian, Winarno (2014) dalam Simamora dan Halim (2015) menjelaskan 
lebih rinci bahwa sumber daya salah satunya berupa SDM.

\section{Badan Layanan Umum}

BLU merupakan salah satu bentuk instansi pemerintah yang memiliki fungsi sebagai agen pemerintah dalam melayani masyarakat. Fungsi tersebut bersifat dinamis dan otonom untuk melaksanakan praktik bisnis yang sehat (business like), tetapi tidak untuk mencari keuntungan dengan tetap mengedepankan efisiensi, efektivitas, dan produktivitas (Waluyo, 2014). Munculnya pola pengelolaan BLU ini sejalan dengan terbitnya Peraturan Pemerintah Nomor 23 Tahun 2005 sebagaimana telah diubah melalui PP Nomor 74 Tahun 2012 tentang Perubahan atas PP 23 Tahun 2005 tentang Pengelolaan Keuangan Badan Layanan Umum. Sesuai dengan peraturan tersebut, BLU diberi otonomi mengelola aset (Lukman, 2013).

\section{Aset Tetap pada BLU}

Berdasarkan PMK Nomor 136 Tahun 2016, aset tetap BLU merupakan aset BLU yang berwujud dimana masa manfaatnya lebih dari 12 bulan untuk digunakan sendiri atau digunakan oleh instansi lain atau dimanfaatkan oleh pihak luar dan/atau masyarakat umum sesuai ketentuan yang berlaku.

\section{Pengelolaan Aset pada BLU}

Berdasarkan PMK Nomor 136 Tahun 2016, dalam mengelola aset, BLU harus memastikan bahwa kegiatan dalam rangka memberikan layanan masyarakat tidak terganggu. Pengelolaan aset pada BLU dilaksanakan dalam bentuk Kerja Sama Operasioanal (KSO) dan Kerja Sama Sumber Daya Manusia dan/atau Manajemen (KSM). Dalam pelaksanaan $\mathrm{KSO}$, mitra berkewajiban membayar sejumlah tertentu sesuai dengan tarif yang berlaku. Tarif tersebut dapat ditetapkan oleh pemimpin BLU sesuai dengan peraturan yang berlaku.

\section{Pemanfaatan Barang Milik Negara (BMN)}

Salah satu proses dalam pengelolaan aset adalah pemanfaatan dimana dari proses tersebut dapat dihasilkan Penerimaan Negara Bukan Pajak (PNBP). Berdasarkan Peraturan Menteri Keuangan Nomor 78/PMK.06/2014 tentang Tata Cara Pelaksanaan Pemanfaatan BMN, pemanfaatan merupakan kegiatan mendayagunakan BMN yang sudah tidak digunakan dalam rangka penyelenggaraan tugas pokok dan fungsi (tusi). Beberapa bentuk pemanfaatan BMN, antara lain Sewa, Pinjam Pakai, Kerja Sama Pemanfaatan (KSP), Bangun Guna Serah (BGS)/Bangun Serah Guna (BSG), serta Kerja Sama Penyediaan Infrastruktur (KSPI).

\section{METODE PENELITIAN}

\section{Desain Penelitian}

Penelitian ini menggunakan pendekatan studi kasus untuk tujuan eksploratif dengan analisis penelitian kualitatif.

\section{Metode Pengumpulan Data}

\section{Wawancara}

Data primer dalam penelitian ini didapatkan melalui wawancara. Saat wawancara, narasumber diberi beberapa pertanyaan yang bersifat probing dengan tujuan menggali pendapat terkait pemanfaatan aset tetap pada BLU. Teknik wawancara dalam penelitian ini adalah wawancara mendalam (in-depth interview). Jenis wawancara yang digunakan adalah wawancara semiterstruktur (semi-structured interviews). Wawancara dilaksanakan secara tatap muka (face-to-face interviews) virtual melalui Video Conference menggunakan aplikasi Zoom Meeting. Pelaksanaan wawancara secara online dipilih karena kondisi saat pengumpulan data sedang tidak kondusif untuk dilakukan pertemuan fisik, yaitu adanya penyebaran wabah Covid-19. 
Wawancara dilakukan kepada tujuh narasumber dari tiga unit kerja yang berbeda. Narasumber dari PKN STAN, yaitu Kepala Subbagian Pengelolaan Aset dan Kerumahtanggaan, Penata BMN Junior, Pengelola BMN Senior, serta Penyaji BMN Senior. Narasumber dari PPK BLU, yaitu Kepala Seksi dan seorang staf Seksi PPK BLU II-C, Subdirektorat PPK-BLU II. Narasumber dari DJKN adalah seorang Staf Senior Seksi BMN IIC, Direktorat BMN. Sedangkan, narasumber pimpinan dari DJKN tidak dapat diwawancarai karena padatnya jadwal pekerjaan yang tidak bisa ditinggalkan.

\section{Telaah Data dan Dokumen}

Data sekunder pada penelitian ini diperoleh melalui telaah beberapa dokumentasi. Dokumen dan data sekunder yang digunakan dalam penelitian ini meliputi: Laporan Keuangan dan Laporan pengelolaan BMN PKN STAN, dokumen beberapa staf di PKN STAN, data dari website resmi PKN STAN, berbagai jurnal dan artikel di internet, beberapa jurnal dari layanan referensi Perpustakaan Nasional RI, beberapa peraturan dari JDIH Kementerian Keuangan, serta beberapa pedoman terkait pengelolaan BLU dari website resmi PPK BLU dan terkait pemanfaatan aset dari website resmi DJKN.

\section{Metode Analisis Data}

Tahap analisis data kualitatif dalam penelitian ini meliputi: data reduction, data display, dan drawing conclusions. Data reduction terdiri dari coding dan pengkategorisasian. Pada proses coding, penelitian ini menggunakan alat bantu berupa software NVivo.

\section{Pengolahan Data Menggunakan \\ Software NVivo}

Coding dalam penelitian ini menggunakan software QSR NVivo 10. Prosedur coding tersebut merujuk pada Bazeley dan Richards (2000) dalam Siswantoro (2016) dan panduan NVivo 10 for windows getting started (2014).
Dokumen transkrip yang sudah rapi diimport ke software NVivo sebagai source. Sources menjadi dasar untuk melakukan analisis. Lima sources dalam penelitian ini diklasifikasikan ke dalam tiga source classifications berdasarkan unit kerja narasumber, yaitu PKN STAN, Pengelola Barang, dan Pembina BLU. Sebelum melakukan coding pada masing-masing source, terlebih dahulu dibuat nodes. Node merupakan tempat untuk memasukkan codes.

Nodes awal dibuat berdasarkan faktor yang telah di-mapping, yaitu terdapat 13 nodes sebagai child nodes yang meliputi: inventarisasi aset, legal audit, penilaian aset, sistem informasi, SDM, peranan dan komitmen pimpinan, peranan regulator, peranan BLU, otonomi atau fleksibilitas BLU, target, tarif, peraturan, serta pengawasan dan pengendalian. Child nodes tersebut diklasifikasikan menjadi dua node classifications, yaitu faktor pendukung dan faktor penghambat sebagai parent nodes. Selanjutnya, masing-masing source di-coding dengan meng-highlight kata atau kalimat yang mengandung makna sama ke dalam suatu node terkait. Kata atau kalimat yang di-highlight tersebut, dalam software NVivo disebut reference.

Selain nodes awal dari hasil mapping, muncul beberapa nodes baru yang diperoleh dari hasil wawancara. Berdasarkan nodes dan sources, hasil coding dibuat matrix coding query. Hasil coding diurutkan dari jumlah reference terbanyak, kemudian dianalisis. Merujuk pada penelitian Satrio (2018), sebagai faktor pendukung dan faktor penghambat utama secara keseluruhan diambil lima nodes dengan jumlah reference terbanyak. Kriteria tersebut didasarkan pada judgement peneliti. Menurut Prabowo dalam webinar Aplikasi NVivo Dasar pada 10 Juli 2020, peneliti dapat menggunakan pendekatannya dalam menganalisis data yang dihasilkan dari pengolahan data menggunakan software Nvivo. 


\section{HASIL DAN PEMBAHASAN}

\section{Faktor-Faktor yang Mendukung Pelaksanaan Pemanfaatan Aset Tetap di BLU}

Berdasarkan hasil coding menggunakan software NVivo, didapatkan lima faktor pendukung utama dalam pelaksanaan pemanfaatan aset tetap di BLU sebagai berikut:

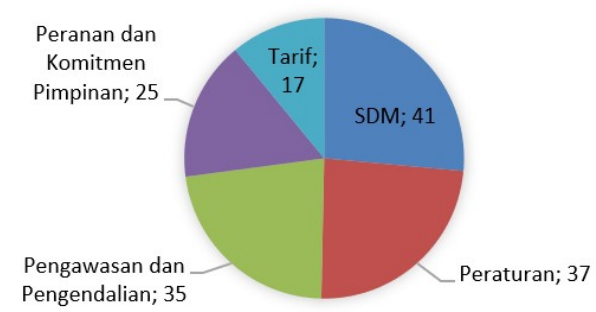

Gambar 1. Faktor Pendukung Utama

Sumber: Coding pada Software NVivo (telah diolah kembali)

Dari gambar 1 terlihat bahwa faktor pendukung utama dalam pelaksanaan pemanfaatan aset tetap di BLU secara urut adalah sebagai berikut:

a. SDM

Narasumber dari DJKN menyatakan bahwa SDM yang memiliki keinginan untuk terus belajar dapat mendukung pelaksanaan pemanfaatan aset. Hasil tersebut dikuatkan dengan teori Edward III dalam Simamora dan Halim (2015) yang mengungkapkan bahwa sumber daya menjadi faktor dominan dalam pengelolaan aset. SDM menjadi komponen sumber daya yang terpenting karena kuantitas dan kualitas SDM akan menentukan efektif atau tidaknya pelaksanaan pemanfaatan aset. Sementara itu, menurut PPK BLU untuk menjadi petugas pengelola pemanfaatan aset di BLU tidak terdapat persyaratan khusus. Namun, SDM pengelola pemanfaatan aset diharapkan memiliki jiwa entrepreneur yang tinggi agar mampu menggali potensi pemanfaatan aset, sehingga menjadi lebih optimal.

Selaras dengan teori Edward III dalam Simamora dan Halim (2015), PPK BLU berpendapat bahwa SDM dalam hal ini mencakup staf dan pemimpin BLU.
Beberapa BLU yang berhasil dalam pemanfaatan aset disebabkan oleh pemimpin BLU yang memiliki koneksi luas dengan pihak luar. Selain itu, PPK BLU menambahkan bahwa pada umumnya, optimalisasi aset di BLU dijalankan oleh suatu divisi khusus, yaitu Divisi Pengembangan Usaha. DJKN juga tidak mempersyaratkan kriteria tertentu bagi SDM pengelola pemanfaatan aset di BLU. Namun, SDM tersebut diharapkan memiliki pemahaman atas aturan terkait pemanfaatan aset. Guna mendukung hal tersebut, DJKN tengah mengembangkan suatu jabatan fungsional di bidang pengelolaan aset, yaitu Penata Laksana Barang. Dengan menjadi jabatan fungsional tersebut, SDM pengelola pemanfaatan diharapkan dapat lebih fokus.

Dalam mencari penerimaan dari pemanfaatan aset dibutuhkan usaha lebih. Oleh karena itu, perlu adanya insentif bagi SDM guna meningkatkan motivasi dan semangat dalam mengelola pemanfaatan aset. Insentif tersebut tidak harus berupa uang, tetapi bisa dalam bentuk pelatihan tambahan atau kesempatan studi banding ke BLU lain di Indonesia dan negara lain. Hal tersebut dapat menambah wawasan SDM terkait pemanfaatan aset. Sehingga, SDM menjadi lebih kompeten dan mahir di bidang pemanfaatan aset. Hal tersebut selaras dengan penelitian Litasari dan Rostin (2018) yang mengungkapkan bahwa perlu adanya pengembangan SDM dengan memberikan pelatihan secara kontinu agar meningkatkan knowledge dan skill. Penelitian Montayop, Ratang, dan Kambu (2017) menambahkan bahwa pelatihan perlu dilaksanakan secara rutin, baik setiap tahun, maupun per semester.

b. Peraturan

DJKN mengungkapkan bahwa adanya peraturan dapat memberikan landasan hukum dan arahan ketentuan bagi para pengambil keputusan. Pentingnya keberadaan peraturan tersebut dikuatkan dengan hasil penelitian Risma (2017) yang menyebutkan bahwa dalam pelaksanaan pemanfaatan perlu adanya peraturan guna 
menghidari kesalahan dalam mengambil keputusan. Sementara itu, Kasubbag Aset PKN STAN mengungkapkan bahwa dalam rangka optimalisasi aset terdapat peraturan yang cukup memberikan fleksibilitas bagi BLU dibanding satker biasa. Diantaranya, dalam hal penetapan tarif dan mekanisme pemanfaatan berupa KSO. KSO dilakukan dengan mekanisme perjanjian kerjasama antara BLU dengan mitra atau investor dimana satker biasa tidak bisa melalui mekanisme tersebut.

Sebagai salah satu regulator yang berwenang menerbitkan peraturan terkait optimalisasi aset di BLU, PPK BLU mengungkapkan bahwa pertimbangan dalam menyusun peraturan khusus bagi BLU terkait pemanfaatan aset, salah satunya PMK Nomor 136 Tahun 2016 adalah untuk memberikan landasan hukum bagi BLU untuk mengoptimalkan aset. Dengan optimalisasi aset diharapkan aset pada BLU bisa berkeringat membiayai dirinya sendiri. Sementara itu, hasil dari terbitnya PMK Nomor 136 Tahun 2016 tersebut, salah satunya adalah PNBP dari optimalisasi aset BLU mengalami kenaikan yang cukup besar.

\section{c. Pengawasan dan Pengendalian}

Sesuai dengan teori keagenan yang diungkapkan Jensen dan Meckling (1976) dalam Setyaningrum (2015) bahwa adanya hubungan antara principal dan agen dapat memicu timbulnya masalah keagenan. Hubungan keagenan menurut Streim (1994) dalam Setyaningrum (2015) disini adalah hubungan antara pemerintah sebagai principal dengan birokrat, dalam hal ini adalah BLU sebagai agen. Pengawasan dan pengendalian sangat diperlukan guna mengatasi masalah dalam hubungan keagenan tersebut. Kasubbag Aset mengungkapkan bahwa DJKN selaku principal bersama unit vertikal di bawahnya diharapkan senantiasa memberikan pembinaan seperti diseminasi dan knowledge sharing bagi BLU.

DJKN mengungkapkan perlunya pengawasan terhadap praktik pemanfaatan aset, serta perlunya sistem pengendalian guna mencapai efektivitas pelaksanaan pemanfaatan aset. BLU memiliki kewajiban untuk melaporkan BMN apa saja yang telah dimanfaatkan dan kontribusinya kepada negara ke dalam sebuah laporan pengawasan dan pengendalian (wasdal) tahunan. DJKN juga akan melakukan pemantauan diantaranya apabila terdapat laporan dari masyarakat atau berita bahwa terdapat BLU yang diindikasikan tidak menyetorkan hasil pemanfaatan ke kas negara atau ke kas operasional BLU, apabila terdapat $\mathrm{BMN}$ idle yang tidak dimanfaatkan sesuai dengan ketentuan, serta apabila ditemukan penyimpangan terkait pengelolaan BMN dari hasil pemeriksaan aparat pemeriksa. Sementara itu, monitoring dan evaluasi (monev) menjadi salah satu upaya pengawasan dan pengendalian oleh PPK BLU.

d. Peranan dan Komitmen Pimpinan

Kasubbag Aset PKN STAN mengungkapkan bahwa peran pimpinan dengan memberikan dorongan dan kesempatan dapat mendukung efektivitas pelaksanaan pemanfaatan aset. Sementara itu, peranan Kasubbag Aset selaku pimpinan sangat penting karena keputusan yang diambil dapat memengaruhi pelaksanaan pemanfaatan aset di PKN STAN. Pengelola BMN mengungkapkan bahwa pimpinan dapat dijadikan sebagai sumber untuk bertanya, berdiskusi, serta selalu mengarahkan apabila terdapat hal yang kurang jelas atau ragu.

Beberapa kebijakan yang pimpinan terapkan terkait pemanfaatan aset di PKN STAN antara lain berkoordinasi dengan mitra untuk menerapkan kenaikan tarif, serta menetapkan target pemanfaatan aset yang meningkat dari tahun ke tahun, tetapi masih feasible untuk dilaksanakan. Target tersebut dimasukkan ke dalam Indikator Kinerja Utama (IKU) staf. Selain itu, untuk mendorong peningkatan hasil pemanfaatan aset, salah satu kebijakan pimpinan adalah meningkatkan jumlah kerjasama. Kebijakan-kebijakan tersebut menjadi implementasi dari teori pilihan 
rasional yang dikemukakan oleh Coleman dan Fararo (1992) dalam Sulistiawati (2016) dimana aktor, dalam hal ini adalah pimpinan akan terus berusaha memaksimalkan aset yang ada dalam rangka pemanfaatan aset.

e. Tarif

Faktor tarif selaras dengan penelitian Putra (2015) yang menyebutkan bahwa perlunya penetapan tarif layanan BLU atas pemanfaatan aset agar bisa dijadikan dasar dalam penarikan biaya dari mitra. PPK BLU mengungkapkan bahwa BLU didorong untuk men-generate income dari semua lini, termasuk dari aset. Setelah ditetapkan menjadi BLU, dalam kurun waktu enam bulan sampai satu tahun, BLU tersebut harus mengusulkan PMK tarif ke Menteri Keuangan. BLU harus membuat kajian ekonomi, kajian hukum, dan kajian teknis. Sementara itu, bagaimana penentuan tarif atau berapa besar tarif diserahkan kepada masing-masing BLU.

Akan tetapi, DJKN memiliki pendapat yang berbeda. Jika pemanfaatan aset terkait dengan tusi BLU, maka tarif boleh ditetapkan dengan peraturan pemimpin BLU. Namun, jika pemanfaatan aset tidak berkaitan dengan tusi BLU, maka tarif ditentukan oleh Pengelola Barang c.q. DJKN, serta objek pemanfaatan harus di-appraisal oleh penilai pemerintah c.q. tim dari DJKN. Pengelola BMN PKN STAN mengungkapkan bahwa penggunaan mekanisme penetapan tarif pemanfaatan aset di PKN STAN tergantung pada kebijakan pimpinan. Kasubbag Aset menjelaskan bahwa pertimbangan pemilihan diantara dua skema penetapan tarif tersebut adalah skema mana yang lebih optimal karena BLU bisa lebih fleksibel dalam penetapan tarif pemanfaatan aset.

Faktor-Faktor yang Menghambat Pelaksanaan Pemanfaatan Aset Tetap di BLU

Berdasarkan hasil coding menggunakan software NVivo, berikut ini faktor penghambat utama dalam pelaksanaan pemanfaatan aset tetap di BLU:

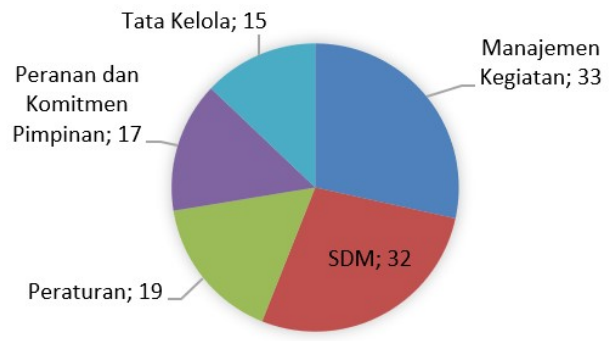

Gambar 2. Faktor Penghambat Utama Sumber: Coding pada Software NVivo (telah diolah kembali)

Dari gambar 2 terlihat bahwa faktor penghambat utama dalam pelaksanaan pemanfaatan aset tetap di BLU secara urut adalah sebagai berikut:

a. Manajemen Kegiatan

Pemanfaatan aset dapat dilaksanakan jika objek pemanfaatan sedang tidak digunakan untuk kegiatan tusi. Sedangkan, menurut Kasubbag Aset manajemen kegiatan di PKN STAN dirasa belum berjalan dengan baik, salah satunya karena masih banyak kegiatan mendadak. Selain itu, penggunaan aset untuk tusi masih tinggi, terutama sejak ada peningkatan jumlah mahasiswa. Gedung dan ruangan nyaris tidak ada yang kosong untuk pelaksanaan pemanfaatan aset, terutama yang bersifat daily, yaitu sewa gedung serba guna. Hal tersebut menjadi salah satu penyebab target dan realisasi dari pemanfaatan aset mengalami penurunan. Selaras dengan yang diungkapkan Octanary (2018) bahwa masih tingginya kebutuhan penggunaan aset tanah dan bangunan untuk melaksanakan kegiatan tusi dari satker menjadi salah satu penyebab pelaksanaan optimalisasi aset masih dalam taraf moderat.

Sementara itu, Pengelola BMN menyebutkan bahwa meskipun mekanisme promosi yang dijalankan PKN STAN adalah marketing pasif, tetapi masyarakat yang berminat untuk menyewa gedung sangat banyak. Namun, karena kurangnya waktu yang tersedia untuk menyewakan gedung tersebut, maka banyak calon mitra 
yang akhirnya ditolak. Hal itu menjadi salah satu penyebab hilangnya potensi pemanfaatan aset di PKN STAN. Selain itu, belum bagusnya manajemen kegiatan juga menghambat PKN STAN untuk memberikan kepastian jadwal gedung yang bisa disewa kepada calon mitra.

Pengelola pemanfaatan aset harus menunggu kalender akademik dari unit lain guna mengetahui kapan gedung tidak digunakan untuk kegiatan tusi. Kalender akademik tersebut berisi tanggal-tanggal dimana gedung tidak dapat disewakan untuk pihak luar. Namun, pada praktiknya, unit tersebut belum memiliki proyeksi kegiatan. Sehingga, kalender akademik diserahkan setelah tahun berjalan. Kasubbag Aset mengungkapkan bahwa dibutuhkan sistem informasi yang advance untuk mengatasi kendala manajemen kegiatan tersebut. Selaras dengan hal tersebut, Yusof (2013) menyebutkan bahwa dalam rangka mencapai efektivitas pengelolaan aset publik dibutuhkan sistem informasi.

b. SDM

Menurut Penata BMN PKN STAN, SDM yang menjadi penghambat adalah SDM yang tidak capable dalam hal pengetahuan teknis dan peraturan. Hal tersebut sesuai dengan penelitian Grubišić, Nušinović, dan Roje (2009) yang menyebutkan bahwa kurangnya SDM yang kompeten dapat menyebabkan pengelolaan aset menjadi tidak efisien. Pada praktiknya, PKN STAN masih membutuhkan SDM yang lebih banyak. Bahkan, pada tahun 2018, seluruh siklus pengelolaan BMN dimana pemanfaatan merupakan salah satu siklus di dalamnya masih di-handle oleh satu staf, sehingga SDM tersebut tidak bisa fokus. Hal tersebut dapat menyebabkan penerimaan dari hasil pemanfaatan aset menjadi tidak stabil. Menurut teori Edward III dalam Simamora dan Halim (2015), kuantitas dan kualitas SDM akan menentukan efektif atau tidaknya pelaksanaan pemanfaatan aset. Selain itu, PKN STAN juga belum memiliki divisi khusus untuk optimalisasi aset. Sementara itu, dalam pelaksanaan pemanfaatan aset berupa KSO belum dibuat tim untuk masing-masing proyek.

Menurut PPK BLU, SDM menjadi penghambat karena masih banyak pemimpin BLU yang tidak paham tentang otonomi BLU yang sangat luas untuk mengoptimalkan aset. Walaupun diberi kewenangan yang luas, beberapa pemimpin BLU masih takut jika optimalisasi aset yang dijalankan justru menjadi temuan aparat pemeriksa. Sehingga, aset masih dikelola ala satker, bukan ala bisnis. Disamping itu, sebagian besar SDM yang ditempatkan di Divisi Pengembangan Usaha pada beberapa BLU masih berpola pikir birokratis dan belum memiliki jiwa bisnis. Hal tersebut selaras dengan penelitian Waluyo (2014) bahwa dalam pengelolaan BLU masih banyak SDM yang cara pandangnya birokratis.

Menurut DJKN, SDM yang menjadi penghambat adalah yang tidak berintegritas. Sehingga, SDM enggan melaporkan adanya indikasi BMN idle di unit kerjanya. Selain itu, di beberapa satker, SDM yang mengelola pemanfaatan aset berganti-ganti. Sehingga, SDM tersebut menjadi tidak fokus dan pemahamannya terkait pemanfaatan aset menjadi kurang mendalam. Hal tersebut selaras dengan penelitian Simamora dan Halim (2015) yang menyebutkan bahwa SDM menjadi faktor kendala utama karena kurangnya pengetahuan terkait pengelolaan aset. Di sisi lain, terdapat unsur reward yang diharapkan oleh para SDM dalam mengelola pemanfaatan aset. Salah satu upaya yang dilakukan DJKN untuk memberikan reward dan guna membuka kesempatan SDM yang ingin fokus mengelola aset adalah dengan mengembangkan jabatan fungsional Penata Laksana Barang.

\section{c. Peraturan}

Menurut Kasubbag Aset, peraturan juga menjadi faktor penghambat karena adanya dualisme antara peraturan yang diterbitkan oleh Pembina BLU dengan peraturan yang diterbitkan oleh Pengelola 
Barang. Hal tersebut selaras dengan penelitian Putra (2015) yang menyebutkan bahwa jika ditinjau dari aturan pemanfaatan aset di BLU, masih terdapat perdebatan antara konsep pemanfaatan untuk tujuan tusi dengan pemanfaatan di luar tusi BLU. Kasubbag Aset menambahkan bahwa peraturan-peraturan terkait pemanfaatan aset di BLU dirasa masih kurang jelas. Sehingga, BLU menjadi ragu dan bingung dalam bertindak.

Kasubbag Aset mengungkapkan bahwa dalam PMK Nomor 78 Tahun 2014 masih terdapat pembatasan-pembatasan, sedangkan dalam PMK Nomor 136 Tahun 2016 tidak memberikan pedoman bagaimana tata cara pengelolaan aset secara detail. Oleh karena itu, dapat dikatakan bahwa kedua regulator penerbit peraturan tersebut memiliki mazhab yang bertolak belakang. DJKN sangat ketat dan lebih menekankan aspek compliance, sedangkan PPK BLU sangat akomodatif dan agresif. Selain itu, dari sisi substansi peraturan juga masih terdapat ketidaksinkronan, baik di level regulasi, maupun operasional. Peraturan dari Pembina BLU mengatur bahwa penerimaan dari semua jenis pemanfaatan aset yang dilakukan oleh BLU dapat disetorkan ke rekening operasional BLU dan diakui sebagai PNBP BLU.

Sedangkan, peraturan dari Pengelola Barang mengatur bahwa penerimaan dari optimalisasi aset untuk kegiatan non tusi dalam rangka layanan penunjang harus disetorkan ke Rekening Kas Umum Negara. Hal itu yang terkadang membuat BLU bingung harus menggunakan peraturan mana. Selain itu, terkait penetapan tarif pemanfaatan, peraturan dari Pembina BLU memberikan kewenangan bagi pemimpin BLU untuk menetapkan tarif pemanfaatan. Namun, peraturan dari Pengelola Barang mewajibkan tarif ditetapkan oleh Pengelola Barang c.q. DJKN dan harus diappraisal oleh tim dari DJKN. Selaras dengan penelitian Waluyo (2018) bahwa di satu sisi, BLU diberikan otonomi yang sangat luas, tetapi dalam praktiknya, masih terdapat kontrol yang kuat dari regulator.

d. Peranan dan Komitmen Pimpinan

Penata BMN mengungkapkan bahwa salah satu permasalahan yang dihadapi selama pelaksanaan pemanfaatan aset adalah kurangnya arahan yang jelas dari pimpinan. Pimpinan cenderung memberikan arahan secara berjenjang. Pimpinan memberikan arahan melalui supervisor, kemudian supervisor meneruskan kepada staf-staf terkait. Selain itu, Penata BMN mengungkapkan bahwa dalam praktiknya, masih banyak tugas lain yang diberikan oleh pimpinan yang bersifat mandatory dan tidak mudah untuk dikerjakan seperti sensus dan revaluasi. Sehingga, staf pengelola pemanfaatan menjadi tidak fokus dalam mengelola pemanfaatan aset karena terlalu luasnya lingkup kerja yang diberikan pimpinan.

Penata BMN menambahkan bahwa pimpinan kurang memprioritaskan optimalisasi aset. Sehingga, staf lebih banyak inisiatif sendiri tanpa diberikan pengarahan. Faktor ini selaras dengan Rorimpandey, Nangoi, dan Manossoh (2016) yang mengungkapkan bahwa terdapat beberapa hambatan dalam praktik pengelolaan aset. Salah satunya adalah kurangnya komitmen dari pimpinan dalam hal pengelolaan aset. Selain itu, kurangnya wawasan teknis dari pimpinan juga menjadi penyebab belum begitu terawasi dan terbinanya pelaksanaan pemanfaatan aset secara internal. Disamping itu, adanya indikasi conflict of interest antar regulator membuat resah pimpinan dalam hal fleksibilitas yang seharusnya dimiliki BLU.

\section{e. Tata Kelola \\ PPK BLU mengungkapkan bahwa} jika BLU hendak memanfaatkan aset yang dimiliki, maka harus dibuat tata kelola. Namun, untuk teknis mekanisme pembuatan tata kelola tersebut diserahkan kepada masing-masing BLU, sehingga BLU disebut self regulated institution. 
Dalam hal ini, BLU diberikan keleluasaan dan otonomi untuk mengoptimalkan aset, tetapi pada praktiknya masih ada BLU yang menyalahgunakan optimalisasi aset tersebut. Dari hasil monev yang dilakukan PPK BLU, terdapat indikasi bahwa tata kelola di beberapa BLU masih belum berjalan dengan baik.

Dari laporan monev, indikator tata kelola rata-rata hanya tercapai di angka $50 \%$ sampai $60 \%$ karena BLU belum mempunyai pengendalian internal yang memadai. Purba (2019) mengungkapkan bahwa faktor tata kelola dapat mengakibatkan pelaksanaan pemanfaatan aset berjalan tidak efektif. Terdapat beberapa satker yang masih melakukan kecurangan atau fraud. Salah satu kecurangan tersebut adalah tidak disetorkannya hasil pemanfaatan aset karena tata kelola yang belum bagus dan karena belum diterapkan standardisasi kerja sesuai dengan ketentuan. PPK BLU mengharapkan agar masing-masing BLU mengembangkan suatu sistem informasi yang dapat mengurangi risiko tersebut.

\section{KESIMPULAN DAN SARAN}

Hasil penelitian menunjukkan bahwa faktor-faktor utama yang mendukung pelaksanaan pemanfaatan aset tetap di PKN STAN adalah SDM, Peraturan, Pengawasan dan Pengendalian, Peranan dan Komitmen Pimpinan, serta Tarif. SDM dalam hal ini bukan hanya staf, tetapi juga pemimpin BLU. SDM yang memiliki jiwa entrepreneurship tinggi dan pengetahuan terkait pemanfaatan aset, yang mempunyai inisiatif untuk terus belajar, serta pemimpin BLU yang memiliki koneksi luas dengan pihak luar dapat mendukung pelaksanaan pemanfaatan aset. Selain itu, pimpinan yang selalu memberikan motivasi bagi staf juga dapat mendukung pelaksanaan pemanfaatan aset. Sementara itu, dari sisi peraturan dirasa cukup memberikan fleksibilitas bagi BLU dibanding satker pada umumnya.
Di sisi lain, faktor-faktor penghambat utama yang menjadi kendala dalam pelaksanaan pemanfaatan aset tetap di PKN STAN adalah Manajemen Kegiatan, SDM, Peraturan, Peranan dan Komitmen Pimpinan, serta Tata Kelola. Manajemen Kegiatan menjadi kendala dalam pemanfaatan berupa sewa yang bersifat daily karena kebutuhan penggunaan aset untuk tusi masih besar, sedangkan manajemen penjadwalan belum bagus. SDM yang menjadi penghambat adalah SDM yang hanya mengetahui peraturan secara garis besar, tidak capable terkait teknis pemanfaatan aset, serta masih menggunakan pola pikir birokratis. Selain itu, pemimpin BLU yang tidak memiliki pemahaman komprehensif terkait kewenangan yang dimiliki juga dapat menjadi penghambat. Sementara itu, dualisme peraturan yang diterbitkan antar regulator dapat menimbulkan keraguan bagi BLU dalam mengambil keputusan.

Beberapa rekomendasi bagi BLU, khususnya PKN STAN antara lain:

a. Perlu penataan SDM dan kelembagaan. BLU diharapkan membuka kesempatan bagi SDM untuk menjadi fungsional Penata Laksana Barang. Untuk pemanfaatan berupa $\mathrm{KSO}$, perlu dibuat tim untuk masing-masing proyek. Untuk pemanfaatan secara keseluruhan, perlu merancang pembentukan Divisi Pengembangan Usaha. Di sisi lain, perlu adanya insentif bagi SDM seperti pemberian pelatihan dan bimbingan teknis, serta pemberian kesempatan untuk studi banding ke BLU lain di Indonesia dan negara lain.

b. Perlu dukungan semua lapisan organisasi, terutama pimpinan. Pimpinan diharapkan dapat memberikan arahan yang jelas dan motivasi kepada semua staf, memerhatikan beban kerja staf, serta membuat prioritas pemanfaatan aset. Pemimpin BLU diharapkan dapat membangun koneksi yang luas dengan pihak luar. Unit terkait diharapkan 
dapat membuat proyeksi kegiatan mahasiswa dan menyusun kalender akademik lebih awal.

c. Agar BLU memakai aturan yang lebih mudah. Namun, perlu diimbangi penguatan sistem pengendalian internal.

d. Agar tarif segera ditetapkan, sehingga bisa menjadi dasar untuk memungut biaya dari mitra. Dalam perhitungan tarif agar melibatkan penilai profesional.

e. BLU diharapkan mengembangkan sistem informasi khusus pemanfaatan aset yang terintegrasi dengan kalender akademik dan bisa diakses oleh masyarakat umum.

Di sisi lain, beberapa rekomendasi bagi regulator antara lain:

a. Perlunya diskusi bersama untuk mengatasi perbedaan pandangan pada masing-masing peraturan terkait pemanfaatan aset tetap di BLU yang telah diterbitkan. Diskusi tersebut diharapkan dapat menghasilkan kebijakan atau peraturan baru yang memberikan kejelasan dan menguatkan fleksibililitas bagi BLU.

b. Regulator diharapkan dapat mengintensifkan pelaksanaan pengawasan dan pengendalian. Salah satunya, pembinaan seperti diseminasi dan knowledge sharing secara berkala.

c. Perlu mengupayakan kebijakan dan mekanisme pemberian insentif bagi SDM pengelola pemanfaatan aset.

Sementara itu, karena beberapa keterbatasan dalam penelitian ini, beberapa rekomendasi bagi peneliti selanjutnya antara lain:

a. Agar pengumpulan data tidak hanya menggunakan metode wawancara, tetapi juga menggunakan metode Focus Group Discussion (FGD) atau survei melalui kuesioner.

b. Perlu perhitungan waktu pelaksanaan wawancara agar tidak bertepatan dengan kesibukan instansi terkait, sehingga memperbesar kesediaan narasumber untuk diwawancarai.

c. Perlu melibatkan narasumber dari instansi vertikal DJKN selaku pembina pengelolaan BMN guna melihat potensi dan kondisi pemanfaatan aset di PKN STAN. Selain itu, perlunya melibatkan narasumber top management untuk mengetahui pertimbangan dalam pengambilan kebijakan secara langsung dari sudut pandang pembuat kebijakan.

d. Perlu studi kasus ke BLU lain yang proses bisnis dan potensinya berbeda dengan PKN STAN seperti Rumah Sakit dan BLU yang lokasinya tidak strategis. Selain itu, karena hasil penelitian ini belum bisa digeneralisasi untuk semua BLU, maka perlu metode penelitian berbeda, misalnya pendekatan empiris dengan analisis penelitian kuantitatif.

e. Meskipun penelitian ini telah memfasilitasi pemahaman yang komprehensif tentang faktor pendukung dan faktor penghambat dalam pelaksanaan pemanfaatan aset tetap di BLU, tetapi masih perlu penelitian lanjutan terkait kendalakendala yang menghambat pelaksanaan pemanfaatan aset tetap di BLU secara mendalam. Salah satunya, terkait dualisme peraturan pemanfaatan aset di BLU yang diterbitkan oleh regulator.

\section{UCAPAN TERIMAKASIH}

Penelitian dan penulisan manuskrip ini tidak terlepas dari doa, bantuan, dan jasa dari berbagai pihak. Penulis mengucapkan terima kasih kepada dosen pembimbing dan penguji penelitian ini, dosen pengajar dan staf tenaga pendidik program studi S1 Ekstensi Akuntansi FEB Universitas Indonesia, Direktur PKN STAN dan Kepala Subbag serta staf PAKRT, narasumber dari Direktorat PPK BLU dan Direktorat BMN DJKN, rekan dan 
dosen PKN STAN, serta Bapak Acwin Hendra Saputra.

\section{DAFTAR PUSTAKA}

Bazeley, P., \& Richards, L. (2000). The NVivo qualitative project book. London: Sage Publications Ltd.

Coleman, J. S., \& Fararo, T. J. (1992). Rational choice theory. Nueva York: Sage publications.

Grubišić, M., Nušinović, M., \& Roje, G. (2009). Towards efficient public sector asset management. Financial theory and practice, 33(3), 329-362.

Inayah. (2010). Studi persepsi faktorfaktor yang mempengaruhi implementasi kebijakan pengelolaan aset daerah di kota Tangerang. (Tesis), Fakultas Ilmu Sosial dan Ilmu Politik, Universitas Indonesia, Jakarta.

Jensen, M. C., \& Meckling, W. H. (1976). Theory of the firm: Managerial behavior, agency costs, and ownership structure. Journal of Financial Economics 3, 305-360.

Lee, R. D., Johnson, R. W., \& Joyce, P. G. (2013). Public budgeting systems ninth edition. Burlington: Jones \& Bartlett Learning.

Litasari, L., \& Rostin, R. (2018). Pengaruh inventarisasi aset, legal audit, dan penilaian aset terhadap optimalisasi pemanfaatan aset tetap pada pemerintah daerah kabupaten kolaka timur. JPEP (Jurnal Progres Ekonomi Pembangunan), 3(2).

Lukman, M. (2013). Badan layanan umum: dari birokrasi menuju korporasi. Jakarta: Bumi Aksara.

Menteri Keuangan Republik Indonesia. (2014). Peraturan Menteri Keuangan Nomor 78/PMK.06/2014 tentang Tata Cara Pelaksanaan Pemanfaatan
BMN, Jakarta: Berita Negara Republik Indonesia Tahun 2014 Nomor 588.

Menteri Keuangan Republik Indonesia. (2015). Rencana Strategis Kementerian Keuangan 20152019. Jakarta: Kementerian Keuangan. Diambil dari https://www.kemenkeu.go.id/media 15418/rencana-strategiskementerian-keuangan-20152019.pdf

Menteri Keuangan Republik Indonesia. (2016). Peraturan Menteri Keuangan Nomor 136/PMK.05/2016 tentang Pengelolaan Aset pada Badan Layanan Umum, Jakarta: Berita Negara Republik Indonesia Tahun 2016 Nomor 1377.

Montayop, P. F., Ratang, W., \& Kambu, A. (2017). Faktor-faktor yang mempengaruhi optimalisasi pemanfaatan aset tetap. Jurnal Kajian Ekonomi dan Keuangan Daerah, 1(2).

NVivo 10 for windows getting started. (2014). United States: QSR International Pty Ltd.

Octanary, D. (2018). Analisis manajemen aset pada satuan kerja pemerintah pusat di kota palu. Katalogis, 6(1).

Politeknik Keuangan Negara STAN. (2020a). Diambil dari http://www.pknstan.ac.id/home/ind ex.html

Politeknik Keuangan Negara STAN. (2020b). Laporan Tanah dan/atau Bangunan Tahun 2019. Diterima dari Tangerang Selatan: SIMAN PKN STAN.

Prabowo, S. (2020, 10 Juli 2020). Tentang: Aplikasi NVivo Dasar [Webinar]. Diambil dari https://www.youtube.com/watch?v $=\mathrm{SWd} q \mathrm{q} \mathrm{fcWvY}$ 
Presiden Republik Indonesia. (2005). Peraturan Pemerintah Nomor 23 Tahun 2005 tentang Pengelolaan Keuangan Badan Layanan Umum, Jakarta: Lembaran Negara Republik Indonesia Tahun 2005 Nomor 48.

Presiden Republik Indonesia. (2012). Peraturan Pemerintah Nomor 74 Tahun 2012 tentang Perubahan atas Peraturan Pemerintah Nomor 23 Tahun 2005 tentang Pengelolaan Keuangan Badan Layanan Umum, Jakarta: Lembaran Negara Republik Indonesia Tahun 2012 Nomor 171.

Purba, R. B. (2019). Pengelolaan aset tetap daerah dalam mengoptimalkan pemanfaatan aset daerah. Jurnal Akuntansi Bisnis dan Publik, 9(2), 152-164.

Putra, F. A. (2015). Analisis tarif penerimaan negara bukan pajak atas pemanfaatan aset badan layanan umum sekolah tinggi akuntansi negara. (Skripsi), Sekolah Tinggi Akuntansi Negara, Tangerang Selatan.

Risma, A. (2017). Pemanfaatan barang milik negara idle dalam bentuk sewa menyewa sebagai upaya penerimaan negara bukan pajak. (Disertasi), Universitas Hasanuddin, Makassar.

Rorimpandey, A., Nangoi, G. B., \& Manossoh, H. (2016). Analisis pengelolaan barang milik daerah menurut peraturan pemerintah nomor 27 tahun 2014 pada pemerintah kabupaten minahasa selatan. Jurnal Accountability, 5(2), 168-177.

Satrio, P. B. (2018). Analisis faktor-faktor penentu kesuksesan penerapan availability payment (AP) pada proyek telekomunikasi kerja sama pemerintah dan badan usaha (KPBU) palapa ring paket barat.
(Skripsi), Politeknik Keuangan Negara STAN, Tangerang Selatan.

Setyaningrum, D. (2015). Kualitas auditor, pengawasan legislatif dan pemanfaatan hasil audit dalam akuntabilitas pengelolaan keuangan daerah. (Disertasi), Program Pascasarjana Ilmu Akuntansi, Universitas Indonesia, Depok.

Simamora, R., \& Halim, A. (2015). Faktor-faktor yang mempengaruhi pengelolaan aset pasca pemekaran wilayah dan pengaruhnya terhadap kualitas laporan keuangan pemerintah di kab. Tapanuli Selatan. Jurnal Ekonomi dan Bisnis, 10(1).

Siswantoro, D. (2016). Rekonstruksi akuntabilitas lembaga wakaf tunai di indonesia. (Disertasi), Fakultas Ilmu Sosial dan Ilmu Politik, Universitas Indonesia, Jakarta.

Streim, H. (1994). Agency problems in the legal political system and supreme auditing institutions. European Journal of Law and Economics, 1(3), 177-191.

Sugiri, D. (2016). Penentuan prioritas usulan anggaran belanja modal dengan pendekatan analytical hierarchy process (ahp): Studi kasus pada badan pendidikan dan pelatihan keuangan. (Tesis), Universitas Indonesia, Jakarta.

Sulistiawati, E. (2016). Faktor-faktor yang mempengaruhi pengelolaan barang milik daerah pada skpd pemerintah kabupaten langkat dengan peranan pimpinan sebagai variabel moderating. (Tesis), Universitas Sumatera Utara, Medan.

Waloejo, H. (2015). Pemanfaatan barang milik negara. Jakarta: Mitra Wacana Media. 
Waluyo, B. (2014). Analisis permasalahan pada implementasi pola pengelolaan keuangan badan layanan umum. Jurnal Infoartha, 3, 27-38.

Waluyo, B. (2018). Balancing financial autonomy and control in agencification: Issues emerging from the Indonesian higher education (Otonomi dan pengendalian keuangan pada badan layanan umum sektor pendidikan). International Journal of Public Sector Management.

Winarno, B. (2014). Kebijakan publik: Teori, proses, dan studi kasus. Yogyakarta: CAPS.

Yusof, Y. (2013). The effectiveness of public sector asset management in Malaysia. (Thesis), Queensland University of Technology, Australia. 